\title{
The Spectrum of Common Mutations in CFTR, AR Gene, and the $Y$ Chromosome Microdeletions and Karyotyping Abnormalities in Phenotypic Male with Very Severe Oligozoospermia
}

kyumars safinejad ( $\square$ q_safinejad@yahoo.com )

Islamic Azad University of Borujerd https://orcid.org/0000-0003-4122-6009

Leyla Jafari

Islamic Azad University Arsanjan

Mahboobeh Nasiri

Islamic Azad University Arsanjan

Mansour Heidari

Tehran University of Medical Sciences

Massoud Houshmand

National Institute for Genetic Engineering and Biotechnology

\section{Research Article}

Keywords: Spectrum, Microdeletions, Karyotyping, Severe Oligozoospermia

Posted Date: May 17th, 2021

DOI: https://doi.org/10.21203/rs.3.rs-482507/v1

License: (c) (i) This work is licensed under a Creative Commons Attribution 4.0 International License.

Read Full License 


\section{Abstract}

Male infertility due to very severe oligozoospermia has been associated with a number of genetic risk factors.This association in patients with sperm concentration lower than $1 \times 10^{6} \mathrm{ml}$ are not yet fully studied.

The present study aims to investigate the distribution of the mutations in the CFTR gene, the CAG repeat expansion of the $A R$ gene as well as $Y$ chromosome microdeletions and karyotyping abnormalities in very severe oligozoospermia patients from the Iranian population.

In the present case-control study 200 severe oligozoospermia and 200 fertile males were enrolled. All patients karyotyped for diagnosis of the chromosomal abnormalities using routine. Microdeletions were evaluated using multiplex PCR. Five common CFTR mutations were genotyped using the ARMS-PCR technique. The CAG repeat expansion in the AR gene was evaluated for the number of repeats in each patient using sequencing.

Overall, $4 \%$ of cases have a numerical and structural abnormality. $7.5 \%$ of patients had a deletion in one of the AZF regions on Yq, and 3.5\% had a deletion in two regions. F508del was the most common (4.5\%) CFTR gene mutation, G542X, and W1282X were detected with $1.5 \%$ and $1 \%$ respectively. One patient was found to have AZFa microdeletion and F508del in heterozygote form; one patient had AZFb microdeletion with F508del. F508del was seen as compound heterozygous with G542X in one patient and with W1282X in the other patient. The difference in the mean of the CAG repeat in the $A R$ gene in patients and controls were statistically significant $(P=0.04)$.

Our study shows that ICSI in couples with very severe oligozoospermia can lead to an increase in children who are at risk of unbalanced chromosomal complement, male infertility due to transmission of $\mathrm{Y}$ chromosomal microdeletion, AR- CAG repeat and cystic fibrosis if both partners carry the CFTR gene mutation. Genetic testing and counseling before considering ICSI is suggested for these couples.

\section{Introduction}

Among numerous types of male infertility, severe oligozoospermia has been described as a condition with a sperm count of less than five million [1]. Hypogonadotropic hypogonadism, genetic polymorphisms, and gene mutations most notably in cystic fibrosis transmembrane conductance regulator (CFTR) and androgen receptor $(A R)$ genes as well as $Y$ chromosome microdeletions are the most common genetic causes of impaired sperm production and male infertility [2]. They are found in 5$10 \%$ of men with severe oligozoospermia [2]. In many cases, diagnosis is performed based on karyotyping, gene mutation screening, and $Y$ chromosome microdeletion detection [3]. Chromosomal anomalies are the most probable cause of male infertility and they are reported 10-time higher in infertile men compared with fertile men [4]. The fundamental role of the $Y$ chromosome in male reproduction is mediated by the genes map on the critical azoospermia factor (AZF) region on the long arm of the chromosome at Yq11 [5]. The AZF is divided into four sub-regions namely AZFa, AZFb, AZFc, and AZFd 
that have no overlap with each other [6]. Any deletion or microdeletion of this region can result in various clinical manifestations in men. AZFa and AZFc deletions lead to Sertoli cell-only syndrome [7] and different clinical outcomes respectively [8]. AZFb sub-region hosts many testis-specific genes such as $P R Y, C D Y 2$, and $R B M Y$ [9]. Finally, the microdeletion of the AZFd is associated with abnormal sperm morphology and mild oligozoospermia [10].

Cystic fibrosis (CF), an inherited life-threatening disease in children and adults, manifests due to mutations in the CFTR gene. CFTR gene encompasses a region of $250 \mathrm{~kb}$ on the $7 \mathrm{q} 31$ chromosome and has 27 exons [11]. More than $95 \%$ of men with CF suffered from infertility because of the congenital bilateral absence of vas deferens (CBAVD) [12]. Although some studies showed that even the heterozygote mutations of the CFTR gene can increase the risk of non-CBAVD male infertility [13-15]. Besides, previous studies reported the association of the CFTR gene mutations with azoospermia form like obstructive and secretary [16]. Also, the proper function of the CFTR channel is essential for sperm fertilization capacity and quality [17].

Androgen receptor (AR) functions as a transcription factor to regulate genes involved in the development of male phenotype and reproductive functions $[18,19]$. Hence, mutations in the gene for this receptor, $A R$ gene, were considered and studied as a potential candidate gene in male infertility [20]. AR gene is located at Xq12 positions and contains 11 exons [21]. Released data showed the prevalence of $A R$ gene mutations $2-3 \%$ among azoospermic and oligozoospermic men [18].

The present study aimed to investigate the prevalence of the known mutations in CFTR and $A R$ genes as well as $Y$ chromosome deletions or microdeletions in a population of men diagnosed as severe oligozoospermia to establish a dataset of severe oligozoospermia-related prevalent mutations in the Iranian population.

\section{Materials And Methods}

\section{Subjects}

The present case-control study included 200 infertile men with very severe oligozoospermia as cases and 200 healthy men as controls. For this study, 200 men were selected from ICSI couples who had at least one year of infertility and semen analysis showing $1 \times 10^{6} \mathrm{ml}$ motile sperm. History taking focused on urogenital development, chronic illness, pulmonary diseases, growth disturbances, medication, male accessory gland infections (MAGI), previous inguinal and scrotal surgery and occupational exposure to heat or chemicals. Abnormalities and ultrasound examination of the contents of the scrotum were performed. Also 200 men of the some age with normal semen analysis who had at least one child and also were recruited during the same time period and had no history of acute pancreatitis, $\mathrm{CP}$, diabetes mellitus (DM), pancreatic adenocarcinoma, and/or apparent biliary or pancreatic diseases, where studied as control samples. Individual analysis was performed twice according to WHO guidelines for semen analysis (WHO, 1992) at least one month apart. Laboratory tests included serum gonadotropins, 
testosterone, prolactin, TSH and sex hormone-binding globulin concentrations. The flowchart in Fig. 1 is illustrated the step-by-step enrollment and exclusion of the cases and controls in the study. All patients were selected from men who were eligible for admission based on our inclusion criteria to highly specialized Academic Center for Education, Culture and Research (ACECR), Qom, Iran between May 2018 and May 2020. Useful information was taken from all subjects using a standard questionnaire. Informed consent to participate in the study was signed in advance by both patients and controls. The study was approved by the Ethics Committee in our local department.

\section{DNA extraction, karyotyping and genotyping}

Venous blood $(5 \mathrm{ml})$ was taken from all participants and divided into 2 tubes including heparin tube and ethylenediaminetetraacetic acid (EDTA)-containing tubes. Lymphocytes of fresh peripheral blood were cultured for $72 \mathrm{~h}$, and metaphase preparations were stained by trypsin-Giemsa banding (GTG) to evaluate each patient's karyotype. At least 30 metaphasic cells were counted and analysed from each participant. EDTA-blood samples were stored at $-20^{\circ} \mathrm{C}$ for further molecular investigations.

Genomic DNA was extracted from EDTA-blood samples using a DNA extraction kit according to the manufacturer's instructions (Cinnagen, Iran). The quality of the extracted DNA was evaluated using Nanodrop spectrophotometry.

\section{Y chromosome microdeletion (AZF region) analysis}

Eight sequences in the AZF region on Yq were selected based on previously reported mutations to detect $\mathrm{Y}$ chromosome microdeletions. Two different sequences evaluated in AZFa (320bp and 326bp), two sequences in AZFb (274bp and $301 \mathrm{bp}$ ) as well as two sequences in AZFc (400bp and 126bp). ZFY (495bp) and $S R Y(472 \mathrm{bp})$ genes were considered as internal controls. The appropriate primers were designed by Oligo5, checked, and blasted in the NCBI primer blast database for specificities and efficiencies (Table 1). 
Table 1

Primers sequences, the amplified product sizes, and annealing temperatures

\begin{tabular}{|c|c|c|c|c|}
\hline Genes & Primers & Primer sequence $\left(5^{\prime}\right.$ to $\left.3^{\prime}\right)$ & Size (bp) & $\mathrm{Ta}\left({ }^{\circ} \mathrm{C}\right)$ \\
\hline \multirow{16}{*}{$\begin{array}{l}\text { AZF } \\
\text { region }\end{array}$} & ZFY-F & ACCGCTGTACTGACTGGTGATTACAC & 495 & \multirow[t]{16}{*}{57} \\
\hline & ZFY-R & GCACCTCTTTGGTATCCGAGAAAGT & 495 & \\
\hline & SRY-F & GAATATTCCCGCTCTCCGGA & 472 & \\
\hline & SRY-R & GCTGGTGCTCCATTCTTGAG & 472 & \\
\hline & AZFa1- F & GTGACACACAGACTATGCTTC & 320 & \\
\hline & AZFa1-R & ACACACAGAGGGACAACCCT & 320 & \\
\hline & AZFb1- F & GGCTCAACCACGAAAAGAAA & 274 & \\
\hline & AZFb1- R & CTGCAGGCAGTAATAAGGGA & 274 & \\
\hline & AZFc1- F & GGGTGTTACCAGAAGGCAAA & 400 & \\
\hline & AZFc1- R & GAACCGTATCTACCAAAGCAGC & 400 & \\
\hline & AZFa2- F & AGAAGGGTCTGAAAGCAGGT & 326 & \\
\hline & AZFa2- R & GCCTACTACCTGGAGGCTTC & 326 & \\
\hline & AZFb2- F & GTCTGCCTCACCATAAACG & 301 & \\
\hline & AZFb2- R & ACCACTGCCAAAACTTTCAA & 301 & \\
\hline & AZFc2- F & GTTACAGGATTCGGCGTGAT & 126 & \\
\hline & AZFc2- R & CTCGTCATGTGCAGCCAC & 126 & \\
\hline \multirow[t]{2}{*}{$A R$ gene } & AR-1-F & GCT GTG AAG GTT GCT GTTCCTCAT & \multirow[t]{2}{*}{ variable } & \multirow[t]{2}{*}{52} \\
\hline & AR-1-R & TCC AGA ATC TGT TCC AGA GCG TGC & & \\
\hline \multirow[t]{9}{*}{ CFTR gene } & $\Delta \mathrm{F} 508$ & GACTTCACTTCTAATGATGATTATGGGAG & 160 & \multirow[t]{9}{*}{$50-53$} \\
\hline & & GTATCTATATTCATCATAGGAAACACCAC & 157 & \\
\hline & & GTATCTATATTCATCATAGGAAACACCAT & & \\
\hline & G542X & GACTTCACTTCTAATGATGATTATGGGAG & 256 & \\
\hline & & ACTCAGTGTGATTCCACCTTCTAC & 257 & \\
\hline & & CACTCAGTGTGATTCCACCTTCTCA & & \\
\hline & $\mathrm{R} 117 \mathrm{H}$ & CACATATGGTATGACCCTCTATATAAACTC & 237 & \\
\hline & & CCTATGCCTAGATAAATCGCGATAGAAC' & 237 & \\
\hline & & CCTATGCCTAGATAAATCGCGATAGAAT & & \\
\hline
\end{tabular}




\begin{tabular}{|c|c|c|c|c|}
\hline Genes & Primers & Primer sequence $\left(5^{\prime}\right.$ to $\left.3^{\prime}\right)$ & Size (bp) & $\mathrm{Ta}\left({ }^{\circ} \mathrm{C}\right)$ \\
\hline & \multirow[t]{3}{*}{ N1303K } & СTCAATTTCTTTATTCTAAAGACATTGG & 328 & \\
\hline & & GATCACTCCACTGTTCATAGGGATCCAAG & 328 & \\
\hline & & GATCACTCCACTGTTCATAGGGATCCAAC & & \\
\hline & \multirow[t]{3}{*}{ W1282X } & СCСАTCACTTTTACCTTATAGGTGGGCCTC & 178 & \\
\hline & & СCTGTGGTATCACTCCAAAGGCTTTCCAC & 178 & \\
\hline & & CCTGTGGTATCACTCCAAAGGCTTTCCAT & & \\
\hline
\end{tabular}

All the above-mentioned sequences were amplified by two separate reactions as multiplex PCR by a thermocycler (Kyratec Thermal Cycler, Australia). For each multiplex-PCR two microtubes were used, each tube includes $3 \mu \mathrm{l}(50-100 \mathrm{ng})$ of DNA template, $5 \mu \mathrm{l}$ of 3 primer pairs for one of the sequences in each AZF region plus 2 primer pairs for internal controls and $12.5 \mu \mathrm{l}$ master mix (Amplicon), and $4.5 \mu \mathrm{l}$ of distilled water.

\section{CFTR gene mutations identification}

The amplification-refractory mutation system (ARMS-PCR) method was used for CFTR-F508del, G542X, N1303K, W1282X, and R117H mutations genotyping. Primers were designed using the primer 3 free online software. Primers sequences and their annealing temperature (Ta) are presented in Table 1. Genotypes were assigned on the agarose gel following electrophoresis based on different sizes of PCR products and staining the gel using DNA safe stain dye (Pishgam Company, Iran).

CAG-repeat length of the androgen receptor (AR) gene investigation

Conventional PCR was used to amplify $A R$-CAG repeats. The primers were designed by Oligo5 software, checked, and blasted by primer blast online software (Table 1).

\section{Statistical analyses}

The statistical analyses were performed using SPSS statistical software (version 16.0, SPSS Inc., Chicago, IL, USA). Distribution of the mutations and chromosomal abnormalities in cases and controls were expressed as number and frequency (percentage). The sequencing graphs were analyzed for the number of CAG repeats in the AR gene using Finch software (https://www.ch.cam.ac.uk/computing/software/finchtv). Fisher's Exact Test was performed in case of CAG repeat analysis.

\section{Results}

\section{Karyotypes}


Karyotypes of 200 very severe oligozoospermia patients showed that $96 \%$ of cases had a normal karyotype.

As shown in Table 2, four of the patients were men with Klinefelter's syndrome (47, XXY) and others have a different structural chromosomal abnormality.

Table 2

Structural and numerical chromosomal abnormalities

\begin{tabular}{|c|c|c|c|}
\hline abnormality & Karyotype & $\mathbf{N}$ & Percent \\
\hline Normal & $46, X Y$ & 192 & $96 \%$ \\
\hline Numerical chromosomal abnormality & $47, X X Y$ & 4 & $2 \%$ \\
\hline \multirow[t]{4}{*}{ Structural } & $45, \mathrm{XY}, \mathrm{rob}(13 ; 14)(\mathrm{q} 10 ; \mathrm{q} 10)$ & 1 & $0.5 \%$ \\
\hline & $46, X Y, \operatorname{inv}(8)(p 22 ; q 21)$ & 1 & $0.5 \%$ \\
\hline & $46, \mathrm{XY}, \mathrm{t}(16 ; 17)(\mathrm{q} 12.1 ; \mathrm{q} 23)$ & 1 & $0.5 \%$ \\
\hline & $46, X Y, t(11 ; 14)(q 13 ; q 24)$ & 1 & $0.5 \%$ \\
\hline \multicolumn{4}{|c|}{ rob: robertsonian translocation, inv: inversion; t: translocation; q: long arm; p: short arm } \\
\hline
\end{tabular}

Differential banding patterns of the amplified sequences of different AZF sub-regions are shown in Fig. 2. As the frequencies in Table 3 show, $89 \%$ of cases had a normal AZF region without any microdeletions in any sub-regions. $7.5 \%$ had microdeletion in only one region and $3.5 \%$ had microdeletion in two regions simultaneously.

Table 3

AZF microdeletions distribution

\begin{tabular}{|lll|}
\hline AZF Mutation & Number & Frequency (\%) \\
\hline Normal & 178 & 89 \\
\hline Microdeletion a & 6 & 3 \\
\hline Microdeletion b & 5 & 2.5 \\
\hline Microdeletion c & 4 & 2 \\
\hline Microdeletion a \& b & 3 & 1.5 \\
\hline Microdeletion b \& c & 4 & 2 \\
\hline
\end{tabular}

CFTR gene Mutations 
The most frequent mutation in the CFTR gene was F508del that accounted for $4.5 \%$ of cases. Two nonsense mutations, G542X and W1282X were the second and third most common mutations in this gene with 1.5 and $1 \%$ respectively. N1303K and R117H occurred at equal frequencies $(0.5 \%)$ in the study population (Table 4). Examples of the amplified mutations are shown in Fig. 2.

Table 4

CFTR gene mutations distribution

\begin{tabular}{|llll|}
\hline Mutations & Protein change & cDNA position & $\begin{array}{l}\text { Mutant cases } \\
\text { (Heterozygote) }\end{array}$ \\
\hline F508del & p.Phe508del & c.1521_1523delCTT & $9(4.5 \%)$ \\
\hline G542X & p.Gly542X & c.1624G > T & $3(1.5 \%)$ \\
\hline W1282X & p.Try1282X & c.3846G > A & $2(1 \%)$ \\
\hline N1303K & p.Asn1303Lys & c.3909C > G & $1(0.5 \%)$ \\
\hline R117H & p.Arg117His & c.350G > A & $1(0.5 \%)$ \\
\hline
\end{tabular}

\section{CAG trinucleotide repeats expansion in AR gene}

The amplified products of the AR-CAG repeat are shown on $2 \%$ agarose gel (Fig. 5). All PCR products were loaded on $8 \%$ acryl amid gel (Fig. 6) and PCR products with different sizes were sequenced. AR gene sequencing showed that $C A G$ repeat in fertile men ranged from 13 to 32 repeats while the expansion of the trinucleotide repeats among severe oligozoospermic men was between 11 and 33 (Fig. 7). The mean number of trinucleotide expansion in severe oligozoospermic men was $25.09 \pm 1.5$ and in fertile men was $23.16 \pm 1.8$. The difference was statistically significant $(P=0.04)$. The most frequent trinucleotide expansions in fertile and infertile men were $25(19 \%)$ and 21 (18\%) respectively. There was no case with 18 repeats in the study cases (Fig. 8).

\section{Case reports}

One patient was heterozygote for F508del and had AZFb deletion. In the other patient, a heterozygote F508del was found with AZFa deletion on the $Y$ chromosome. In one patient, the F508del was found in the compound heterozygous form with W1282X and one patient in the form of compound heterozygous with G542X. The overall frequency of the patients with two different genetic changes in the CFTR gene and/or Y chromosome was $2 \%$ (Table 5 ). 
Table 5

The simultaneous occurrence of genetic changes in Yq or CFTR and AR genes

\begin{tabular}{|llllllll|}
\hline F508del & G542X & R117H & W1282X & AZFa & AZFb & number & Frequency (\%) \\
\hline$\sqrt{ }$ & & & & $\sqrt{ }$ & & 1 & 0.5 \\
$\sqrt{ }$ & & & & & $\sqrt{ }$ & 1 & 0.5 \\
$\sqrt{ }$ & $\sqrt{ }$ & & & & & 1 & 0.5 \\
$\sqrt{ }$ & & & $\sqrt{ }$ & & & 1 & 0.5 \\
\hline
\end{tabular}

\section{Discussion}

The successful application of current assisted reproductive technologies used for infertile couples requires a precise understanding of the involved genetic factors as one of the important causes of male factor infertility [22]. Therefore, in this study, some common genetic risk factors such as chromosomal abnormalities, Y chromosome microdeletions, CFTR gene mutations, and length of the CAG repeat in the $\mathrm{N}$-terminal transactivation domain of the $A R$ gene in severe oligozoosperimc Iranian men were investigated and compared with fertile men as a control group.

We found chromosomal abnormality at a rate of $4 \%$ (8 individuals) of severe oligozoospermic men which is consistent with previous studies reporting the range of occurred abnormalities between $2 \%-16 \%$ in infertile patients $[23,24]$. Foresta et al in 2005 studied 750 oligozoospermic men and reported a frequency of $5.6 \%$ for chromosomal aberrations, and klinefelter was the most chromosomal abnormality in patients [25]. In the case of klinefelter syndrome as the most common karyotype abnormality in men with severe male factor infertility, four patients $(2 \%)$ have been identified, while structural chromosomal abnormalities including robertsonian translocations, chromosomal inversions, and translocations 16;17 and $11 ; 14$, overall accounted for $2 \%$ (Table 2). Our results were consistent with the obtained data of a study on 935 infertile men whose karyotypes were evaluated and the rate of $6.9 \%$ of chromosomal abnormalities was reported [26]. A smaller sample size, different inclusion criteria, and ethnicity may justify the slight differences in the data between the two studies. The probability of producing unbalanced genetic content gametes and abnormal sperm in men with chromosomal translocation is higher, whereas in men with robertsonian translocation a wide range of $3.4 \%-40 \%$ abnormal sperm have been observed [27].Previous studies have reported the frequency of $Y$ chromosome microdeletions as the second leading cause of spermatogenic failure [28], varies from 1 to $58 \%$ across the world [29-31]. The most prevalent and frequent deletion occurs in AFZc (approximately $80 \%$ ) following by those in AZFb (1$5 \%)$, AZFa (0.5-4\%), and AZFbc (1-3\%) [28]. The differences in patients enrollment criteria, sample size, used STS primers, ethnical and geographical and other genetic backgrounds and environmental influences may lead to variation in reported frequencies [29, 31-33].

Inconsistent with most of the previous reports in which AFZc was the most frequent Yq deletion [33-36], our data showed that deletions occurred most frequently in the AZFa sub-region (3\%). While it is well 
documented that men with AZFc deletions and partial deletions in AZFb show different types of fertility status from normal fertility to oligozoospermia and azoospermia [37, 38]. In Kim et al study that was done in Korea, most microdeletion in severe oligozoospermia belongs to AZFc (87.1\%) and then AZFb (36\%)[5].Screening of $Y$ chromosome microdeletions as a diagnostic, prognostic and preventive tool has great importance.Although the genetic correlation between CFTR gene mutations and male infertility due to CBAVD is well documented, recently, it has been found to play roles in other forms of male infertility besides the CBAVD phenotype. However, the link between the alteration of sperm parameters and CFTR seems to be weak and remains largely unknown [25, 39-41]. There is some evidence about the involvement of CFTR protein in reducing the cytoplasmic volume of sperm during spermiogenesis that is derived from a study on rat testicular tissue in which CFTR mRNA restriction to pre-meiotic round spermatids and principle cells, covering the primary part of the human and rodent epididymis, was observed [42].However, different studies on the frequency of CFTR mutations in infertile males without CBAVD have been reported contradictory results, while in some cohorts it was found that the elevation of CFTR mutation rate is associated with reduced sperm quality [43], male idiopathic infertility [44] and cryptozoospermia [45]. In contrast, others detected no increase in CFTR mutation frequency in males with non-obstructive azoospermia or oligoasthenoteratozoospermia $[40,46]$. Therefore, the necessity of CFTR mutations screening in infertile men before intracytoplasmic sperm injection (ICSI) for example, has not been yet fully defined. In the present study, the total frequency of CFTR mutations was $8 \%$, which is in agreement with a study on the male of the German population with reduced sperm quality who were evaluated in the case of CFTR mutation frequency. In Schulz et al study $7.69 \%$ of patients with severe oligozoospermia had a single CFTR mutation [47]. It should be noted that other studies have been reported no difference between the two groups in the case of CFTR variants between Italian people cases and controls [16, 25].Regarding androgen receptor-CAG trinucleotide repeat, our findings revealed the association between the increase in CAG-repeat expansion and the risk of severe oligozoospermia in men. There is not any standard relationship between CAG-repeat length and the risk of male infertility due to previous reports [48-50]. The correlation between CAG repeat length and Kennedy's disease has been reported [51-53]. While this gene is located on the X chromosome, applying ICSI to treat patients with severe oligozoospermia may raise the potential risk of Kennedy disease in 2 generations (54). Also, it has been reported that AR binding activity in infertile male is decreased [55-57]. The mechanism by which CAG repeat length may affect fertility is still unknown. But in studies that have investigated the role of ARCAG repeats in some diseases, three pathogenic mechanisms including loss of protein function, the gain of protein function, and the gain of function of RNA containing CUG repeats are suggested [58). To find the exact role of the mentioned mechanisms in male infertility future studies are needed. Komori et al reported that mean of CAG repeat in oligozoospermic men was 21.4 and in the control group was 21.2, so their study was inconsistent with our data[59]. In the current study the difference between two groups was significantly and the mean CAG repeat in the case and control group was 25.09 and 23.16 respectively. Our data were consistent with Patrizio et al study that reported CAG- repeat length in oligozoospermic men was 25.04 and in fertile men was 22[54]. In Mobasseri et al study in 2018, there was no significant difference between the two groups (Case 18.34 and control 17.53 CAG repeat length) so inconsistent with our study [22].It is necessary for couples with chromosomal structural abnormalities 
to have genetic counseling and apply a preimplantation genetic diagnosis test. Unfortunately, we did not assay the abnormal sperm ratio in men with chromosomal abnormalities in comparison with those without and this could be considered as the main limitation of our study.

\section{Declarations}

\section{Acknowledgements}

The authors would like to thank all patients and controls for his kind cooperation in this study.

\section{Funding}

No funding was received to assist with the preparation of this manuscript.

\section{Author information}

\section{Affiliations}

1. Department of Biology, Arsanjan Branch, Islamic Azad University, Arsanjan, Iran

Leyla Jafari \& Mahboobeh Nasiri

\section{Department of Biology, Borujerd Branch, Islamic Azad University, Borujerd, Iran}

Kyumars Safinejad [*Corresponding author:q_safinejad@yahoo.com]

3. Department of Medical Genetics, Tehran University of Medical Sciences(TUMS), Poursina Ave, Tehran, Iran

Mansour Heidari

\section{National Institute for Genetic Engineering and Biotechnology, Tehran, Iran}

Massoud Houshmand

\section{Contributions}

$\mathrm{KS}$, general coordinator, who created the project. KS and $\mathrm{MN}$ designed the research study, organizated the project and performed the research. $L J$ performed PCR based experiments and analysis of DNA sequencing data.MH and $\mathrm{MHM}$ analysed the data and performed statistical analysis. $\mathrm{KS}, \mathrm{L} J$ and $\mathrm{MN}$ wrote comprehensive literature review. $\mathrm{KS}$ and $\mathrm{L} J$ wrote the paper. All authors approved the final version of the manuscript and submission of the manuscript.

\section{Corresponding author}

Correspondence to Kyumars Safinejad. 


\section{Ethics declarations}

\section{Conflicts of interest}

The authors declare no conflict of interest regarding this publication.

\section{Ethics approval}

The study was approved by the Ethics Committee in our local department [highly specialized Academic Center for Education, Culture and Research (ACECR) on May 2018].

\section{Informed consent}

Useful information was taken from all subjects using a standard questionnaire. Informed consent to participate in the study was signed in advance by both patients and controls. All authors give consent for participation of the current study. All authors give consent for publication of the manuscript in Molecular Biology Reports.

\section{References}

1. Wosnitzer MS. Genetic evaluation of male infertility. Translational andrology and urology. 2014;3(1):17-26.

2. Krausz C, Riera-Escamilla A. Genetics of male infertility. Nature Reviews Urology. 2018;15(6):369-84.

3. Çinar Ç, Yazıcı C, Ergünsu Ş, Beyazyürek Ç, Javadova D, Sağlam Y, et al. Genetic diagnosis in infertile men with numerical and constitutional sperm abnormalities. Genetic testing. 2008;12(2):195-202.

4. Kovacheva K, Kotsev R, Konova E, Rilcheva V, Kamburova Z, Simeonova M. Chromosomal abnormalities and $\mathrm{Y}$ chromosome microdeletions in Bulgarian male with azoospermia or severe oligospermia. Journal of IMAB-Annual Proceeding Scientific Papers. 2018;24(4):2217-22.

5. Kim MJ, Choi HW, Park SY, Song IO, Seo JT, Lee H-S. Molecular and cytogenetic studies of 101 infertile men with microdeletions of $Y$ chromosome in 1,306 infertile Korean men. Journal of assisted reproduction and genetics. 2012;29(6):539-46.

6. Foresta C, Moro E, Ferlin A. Y chromosome microdeletions and alterations of spermatogenesis. Endocrine reviews. 2001;22(2):226-39.

7. Ferlin A, Moro E, Rossi A, Dallapiccola B, Foresta C. The human Y chromosome's azoospermia factor $b(A Z F b)$ region: sequence, structure, and deletion analysis in infertile men. Journal of medical genetics. 2003;40(1):18-24.

8. Liu XY, Wang RX, Fu Y, Luo LL, Guo W, Liu RZ. Outcomes of intracytoplasmic sperm injection in oligozoospermic men with Y chromosome AZF b or AZF c microdeletions. Andrologia. 2017;49(1):e12602.

9. Suganya J, Kujur SB, Selvaraj K, Suruli MS, Haripriya G, Samuel CR. Y Chromosome Microdeletions and Partial AZFc Deletions in Infertile Men from South India. Journal of Advances in Medicine and 
Medical Research. 2016:1-10.

10. Ceylan G, Ceylan C, Elyas H. Genetic anomalies in patients with severe oligozoospermia and azoospermia in eastern Turkey: a prospective study. Genet Mol Res. 2009;8(3):915-22.

11. Ellsworth RE, Jamison DC, Touchman JW, Chissoe SL, Braden Maduro VV, Bouffard GG, et al. Comparative genomic sequence analysis of the human and mouse cystic fibrosis transmembrane conductance regulator genes. Proceedings of the National Academy of Sciences of the United States of America. 2000;97(3):1172-7.

12. Ghorbel M, Baklouti-Gargouri S, Keskes R, Sellami-Ben Hamida A, Feki-Chakroun N, Bahloul A, et al. Screening of $\triangle F 508$ mutation and IVS8-poly T polymorphism in CFTR gene in Tunisian infertile men without CBAVD. Andrologia. 2012;44:376-82.

13. Safinejad K, Darbouy M, Kalantar SM, Zeinali S, Mirfakhraie R, Yadegar L, et al. The prevalence of common CFTR mutations in Iranian infertile men with non-CAVD obstructive azoospermia by using ARMS PCR techniques. Journal of assisted reproduction and genetics. 2011;28(11):1087-90.

14. Mocanu E, Shattock R, Barton D, Rogers M, Conroy R, Sheils O, et al. All azoospermic males should be screened for cystic fibrosis mutations before intracytoplasmic sperm injection. Fertility and sterility. 2010;94(6):2448-50.

15. Stuppia L, Antonucci I, Binni F, Brandi A, Grifone N, Colosimo A, et al. Screening of mutations in the CFTR gene in 1195 couples entering assisted reproduction technique programs. European journal of human genetics. 2005;13(8):959-64.

16. Tamburino L, Guglielmino A, Venti E, Chamayou S. Molecular analysis of mutations and polymorphisms in the CFTR gene in male infertility. Reprod Biomed Online. 2008;17(1):27-35.

17. Li C-Y, Jiang L-Y, Chen W-Y, Li K, Sheng H-Q, Ni Y, et al. CFTR is essential for sperm fertilizing capacity and is correlated with sperm quality in humans. Human reproduction. 2010;25(2):317-27.

18. Ferlin A, Arredi B, Foresta C. Genetic causes of male infertility. Reproductive toxicology. 2006;22(2):133-41.

19. Nilsson EM, Laursen KB, Whitchurch J, McWilliam A, Ødum N, Persson JL, et al. MiR137 is an androgen regulated repressor of an extended network of transcriptional coregulators. Oncotarget. 2015;6(34):35710.

20. Ferlin A, Vinanzi C, Garolla A, Selice R, Zuccarello D, Cazzadore C, et al. Male infertility and androgen receptor gene mutations: clinical features and identification of seven novel mutations. Clinical endocrinology. 2006;65(5):606-10.

21. Tan MH, Li J, Xu HE, Melcher K, Yong EL. Androgen receptor: structure, role in prostate cancer and drug discovery. Acta pharmacologica Sinica. 2015;36(1):3-23.

22. Mobasseri N, Babaei F, Karimian M, Nikzad H. Androgen receptor (AR)-CAG trinucleotide repeat length and idiopathic male infertility: a case-control trial and a meta-analysis. EXCLI journal. 2018;17:1167.

23. Ferlin A, Raicu F, Gatta V, Zuccarello D, Palka G, Foresta C. Male infertility: role of genetic background. Reproductive biomedicine online. 2007;14(6):734-45. 
24. Fu L, Xiong D-K, Ding X-P, Li C, Zhang L-Y, Ding M, et al. Genetic screening for chromosomal abnormalities and $Y$ chromosome microdeletions in Chinese infertile men. Journal of assisted reproduction and genetics. 2012;29(6):521-7.

25. Foresta C, Garolla A, Bartoloni L, Bettella A, Ferlin A. Genetic abnormalities among severely oligozoospermic men who are candidates for intracytoplasmic sperm injection. The Journal of Clinical Endocrinology \& Metabolism. 2005;90(1):152-6.

26. Bourrouillou G, Dastugue N, Colombies P. Chromosome studies in 952 infertile males with a sperm count below 10 million/ml. Hum Genet. 1985;71(4):366-7.

27. Jaarola M, Martin RH, Ashley T. Direct evidence for suppression of recombination within two pericentric inversions in humans: a new sperm-FISH technique. The American Journal of Human Genetics. 1998;63(1):218-24.

28. Krausz C, Hoefsloot L, Simoni M, Tüttelmann F. EAA/EMQN best practice guidelines for molecular diagnosis of Y-chromosomal microdeletions: state-of-the-art 2013. Andrology. 2014;2(1):5-19.

29. Suganthi R, Vijesh VV, Vandana N, Fathima Ali Benazir J. Y choromosomal microdeletion screening in the workup of male infertility and its current status in India. Int J Fertil Steril. 2014;7(4):253-66.

30. Ferlin A, Raicu F, Gatta V, Zuccarello D, Palka G, Foresta C. Male infertility: role of genetic background. Reprod Biomed Online. 2007;14(6):734-45.

31. O'Flynn O'Brien KL, Varghese AC, Agarwal A. The genetic causes of male factor infertility: a review. Fertil Steril. 2010;93(1):1-12.

32. Stouffs K, Seneca S, Lissens W. Genetic causes of male infertility. Annales d'endocrinologie. 2014;75(2):109-11.

33. Balkan $\mathrm{M}$, Tekes $\mathrm{S}$, Gedik A. Cytogenetic and $\mathrm{Y}$ chromosome microdeletion screening studies in infertile males with Oligozoospermia and Azoospermia in Southeast Turkey. J Assist Reprod Genet. 2008;25(11-12):559-65.

34. Pina-Neto J, Carrara R, Bisinella R, Mazzucatto L, Martins M, Sartoratto E, et al. Somatic cytogenetic and azoospermia factor gene microdeletion studies in infertile men. Brazilian journal of medical and biological research. 2006;39(4):555-61.

35. Stahl PJ, Masson P, Mielnik A, Marean MB, Schlegel PN, Paduch DA. A decade of experience emphasizes that testing for $Y$ microdeletions is essential in American men with azoospermia and severe oligozoospermia. Fertility and sterility. 2010;94(5):1753-6.

36. Chellat D, Rezgoune ML, McElreavey K, Kherouatou N, Benbouhadja S, Douadi H, et al. First study of microdeletions in the $\mathrm{Y}$ chromosome of Algerian infertile men with idiopathic oligo-or azoospermia. Urologia Internationalis. 2013;90(4):455-9.

37. KLEMETTI R, RAITANEN J, SIHVO S, SAARNI S, KOPONEN P. Infertility, mental disorders and wellbeing - a nationwide survey. Acta Obstetricia et Gynecologica Scandinavica. 2010;89(5):677-82.

38. Khabour OF, Fararjeh AS, Alfaouri AA. Genetic screening for AZF Y chromosome microdeletions in Jordanian azoospermic infertile men. International journal of molecular epidemiology and genetics. 2014;5(1):47. 
39. Stuhrmann M, Dörk T. CFTR gene mutations and male infertility. Andrologia. 2000;32(2):71-83.

40. Ravnik-Glavač M, Svetina N, Zorn B, Peterlin B, Glavač D. Involvement of CFTR gene alterations in obstructive and nonobstructive infertility in men. Genetic testing. 2001;5(3):243-7.

41. Larriba S, Bonache S, Sarquella J, Ramos M, Gimenez J, Bassas L, et al. Molecular evaluation of CFTR sequence variants in male infertility of testicular origin. international journal of andrology. 2005;28(5):284-90.

42. Cheung K, Leung C, Leung G, Wong P. Synergistic effects of cystic fibrosis transmembrane conductance regulator and aquaporin-9 in the rat epididymis. Biology of reproduction. 2003;68(5):1505-10.

43. van der Ven $\mathrm{K}$, Messer $\mathrm{L}$, van der Ven $\mathrm{H}$, Jeyendran RS, Ober $\mathrm{C}$. Cystic fibrosis mutation screening in healthy men with reduced sperm quality. Human reproduction. 1996;11(3):513-7.

44. Jakubiczka S, Bettecken T, Stumm M, Nickel I, Musebeck J, Krebs P, et al. Frequency of CFTR gene mutations in males participating in an ICSI programme: Brief communication. Human Reproduction. 1999;14(7):1833-4.

45. Cruger D, Agerholm I, Byriel L, Fedder J, Bruun-Petersen G. Genetic analysis of males from intracytoplasmic sperm injection couples. Clinical genetics. 2003;64(3):198-203.

46. Boucher D, Creveaux I, Grizard G, Jimenez C, Hermabessiere J, Dastugue B. Screening for cystic fibrosis transmembrane conductance regulator gene mutations in men included in an intracytoplasmic sperm injection programme. Molecular human reproduction. 1999;5(6):587-93.

47. Schulz S, Jakubiczka S, Kropf S, Nickel I, Muschke P, Kleinstein J. Increased frequency of cystic fibrosis transmembrane conductance regulator gene mutations in infertile males. Fertil Steril. 2006;85(1):135-8.

48. Delli Muti N, Agarwal A, Buldreghini E, Gioia A, Lenzi A, Boscaro M, et al. Have androgen receptor gene CAG and GGC repeat polymorphisms an effect on sperm motility in infertile men? Andrologia. 2014;46(5):564-9.

49. Nenonen H, Björk C, Skjaerpe P-A, Giwercman A, Rylander L, Svartberg J, et al. CAG repeat number is not inversely associated with androgen receptor activity in vitro. MHR: Basic science of reproductive medicine. 2009;16(3):153-7.

50. Khan HL, Bhatti S, Abbas S, Khan YL, Aslamkhan M, Gonzalez RMM, et al. Tri-nucleotide consortium of androgen receptor is associated with low serum FSH and testosterone in asthenospermic men. Systems biology in reproductive medicine. 2018;64(2):112-21.

51. La Spada AR, Roling DB, Harding AE, Warner CL, Spiegel R, Hausmanowa-Petrusewicz I, et al. Meiotic stability and genotype - phenotype correlation of the trinucleotide repeat in $\mathrm{X}$-linked spinal and bulbar muscular atrophy. Nature Genetics. 1992;2(4):301-4.

52. Biancalana V, Serville F, Prommier J, Julien J, Hanauer A, Mandel JL. Moderate instability of the trinucleotide repeat in spino bulbar muscular atrophy. Human Molecular Genetics. 1992;1(4):255-8.

53. Doyu M, Sobue G, Mitsuma T, Uchida M, Iwase T, Takahashi A. Very late onset X-linked recessive bulbospinal neuronopathy: mild clinical features and a mild increase in the size of tandem CAG 
repeat in androgen receptor gene. J Neurol Neurosurg Psychiatry. 1993;56(7):832-3.

54. Patrizio P, Leonard DG, CHEN KL, HERNANDEZ-AYUP S, Trounson AO. Larger trinucleotide repeat size in the androgen receptor gene of infertile men with extremely severe oligozoospermia. Journal of andrology. 2001;22(3):444-8.

55. Aiman J, Griffin JE, Gazak JM, Wilson JD, MacDonald PC. Androgen Insensitivity as a Cause of Infertility in Otherwise Normal Men. New England Journal of Medicine. 1979;300(5):223-7.

56. Aiman J, Griffin JE. The frequency of androgen receptor deficiency in infertile men. The Journal of clinical endocrinology and metabolism. 1982;54(4):725-32.

57. Akin JW, Behzadian A, Tho SP, McDonough PG. Evidence for a partial deletion in the androgen receptor gene in a phenotypic male with azoospermia. Am J Obstet Gynecol. 1991;165(6 Pt 1):18914.

58. La Spada AR, Taylor JP. Repeat expansion disease: progress and puzzles in disease pathogenesis. Nature Reviews Genetics. 2010;11(4):247-58.

59. Komori S, Kasumi H, Kanazawa R, Sakata K, Nakata Y, Kato H, et al. CAG repeat length in the androgen receptor gene of infertile Japanese males with oligozoospermia. Molecular human reproduction. 1999;5(1):14-6.

\section{Figures}




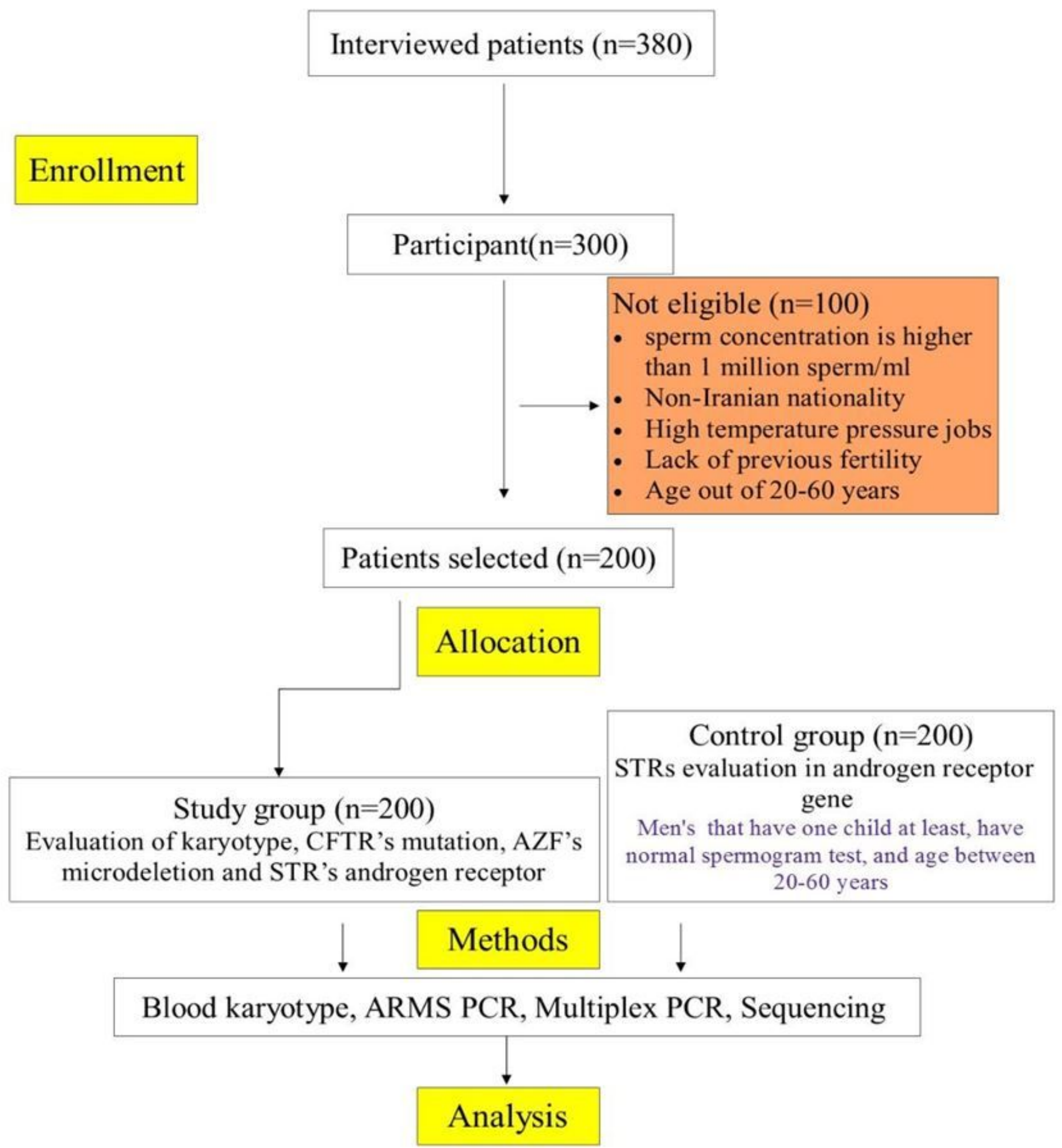

Figure 1

Study flowchart 


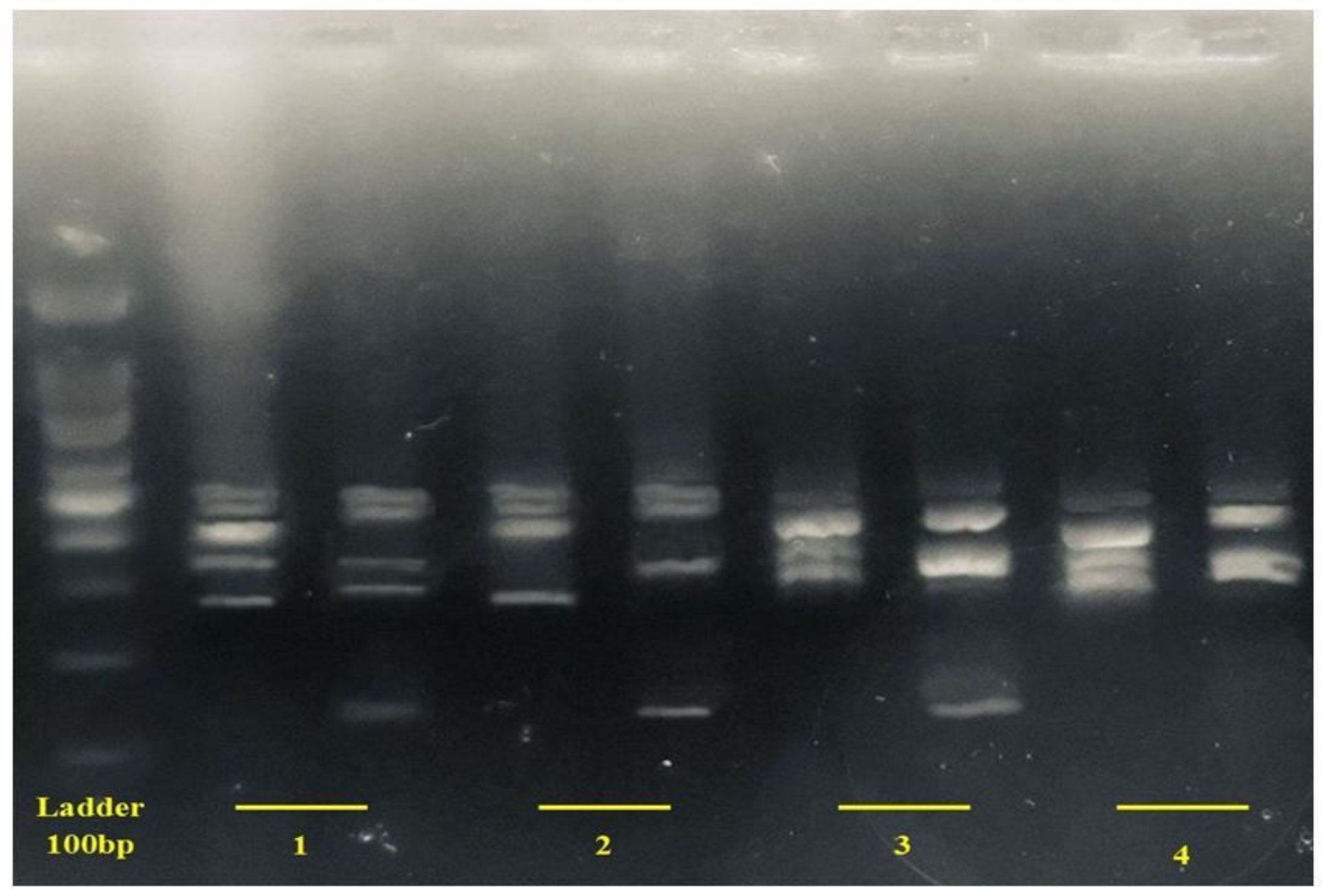

\section{Figure 2}

1. Electrophoretic patterns of different Yq AZF microdeletions on agarose electrophoresis. Normal 2. AZFa microdeletion 3. AZFb microdeletion 4. AZFc microdeletion 


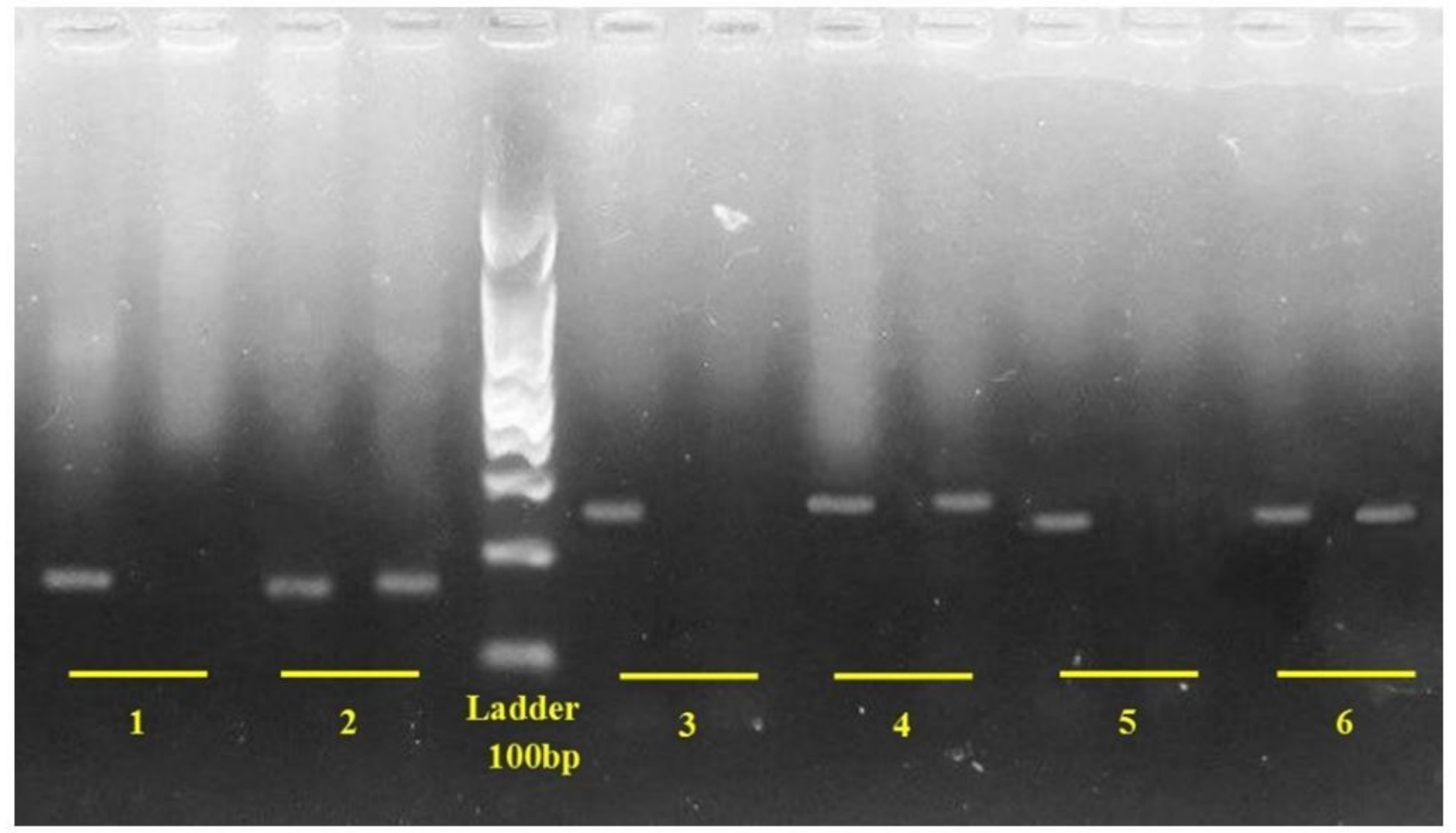

\section{Figure 3}

CFTR gene mutations genotyping on $2 \%$ agarose gel electrophoresis. 1. W1282X normal (178bp) 2 . W1282X heterozygote (178bp) 3. G542X normal (257bp) 4. G542X heterozygote (256bp) 5. R117H normal (237bp) 2. R117H heterozygote (237bp) 


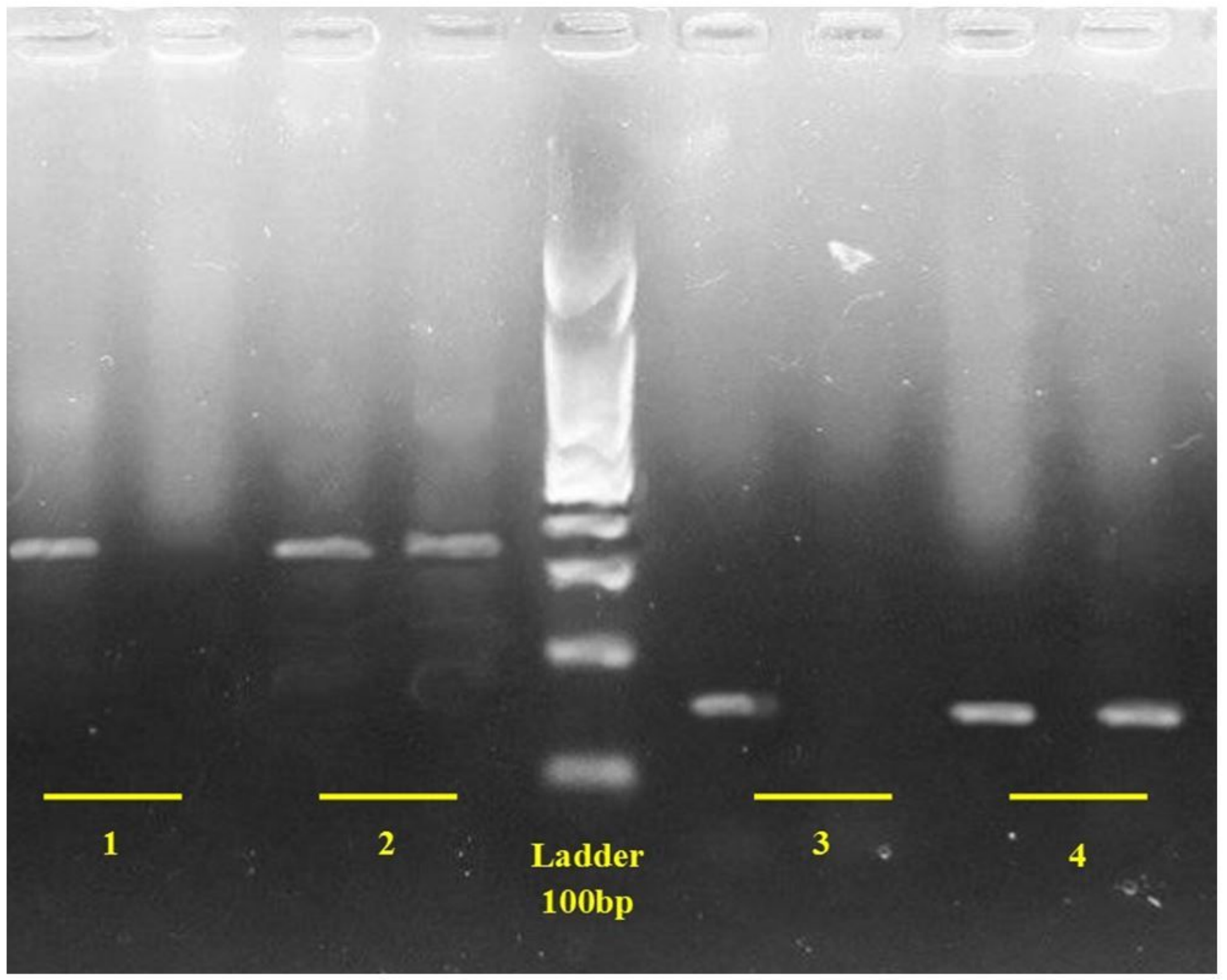

Figure 4

CFTR gene mutations genotyping on $2 \%$ agarose gel electrophoresis. 1. N1303K normal (328bp) 2 . N1303K heterozygote (328bp) 3. F508del normal (160bp) 4. F508del heterozygote (157bp) 


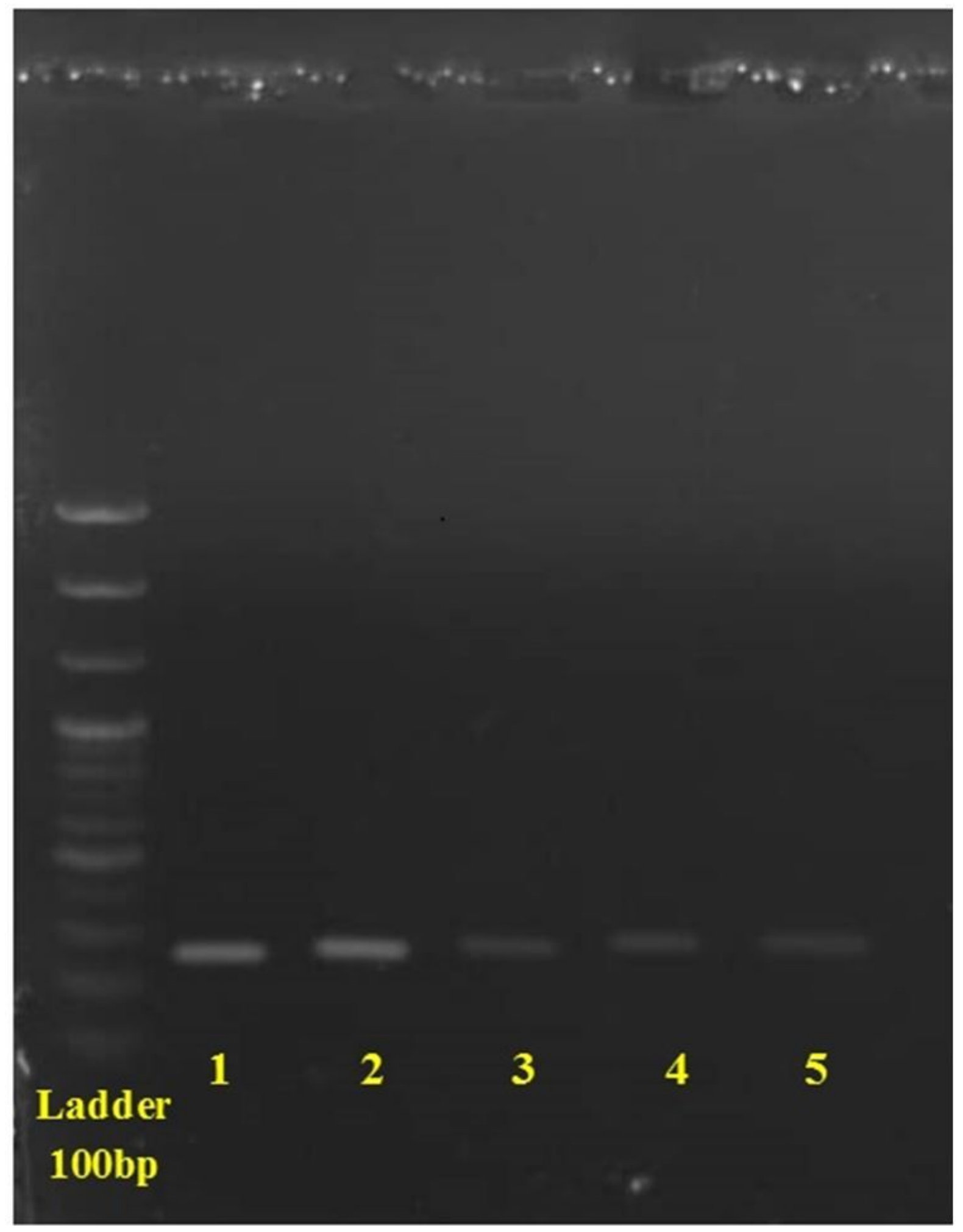

Figure 5

AR- CAG repeat expansion amplification using PCR. 1 to 5: 285-300 bp 


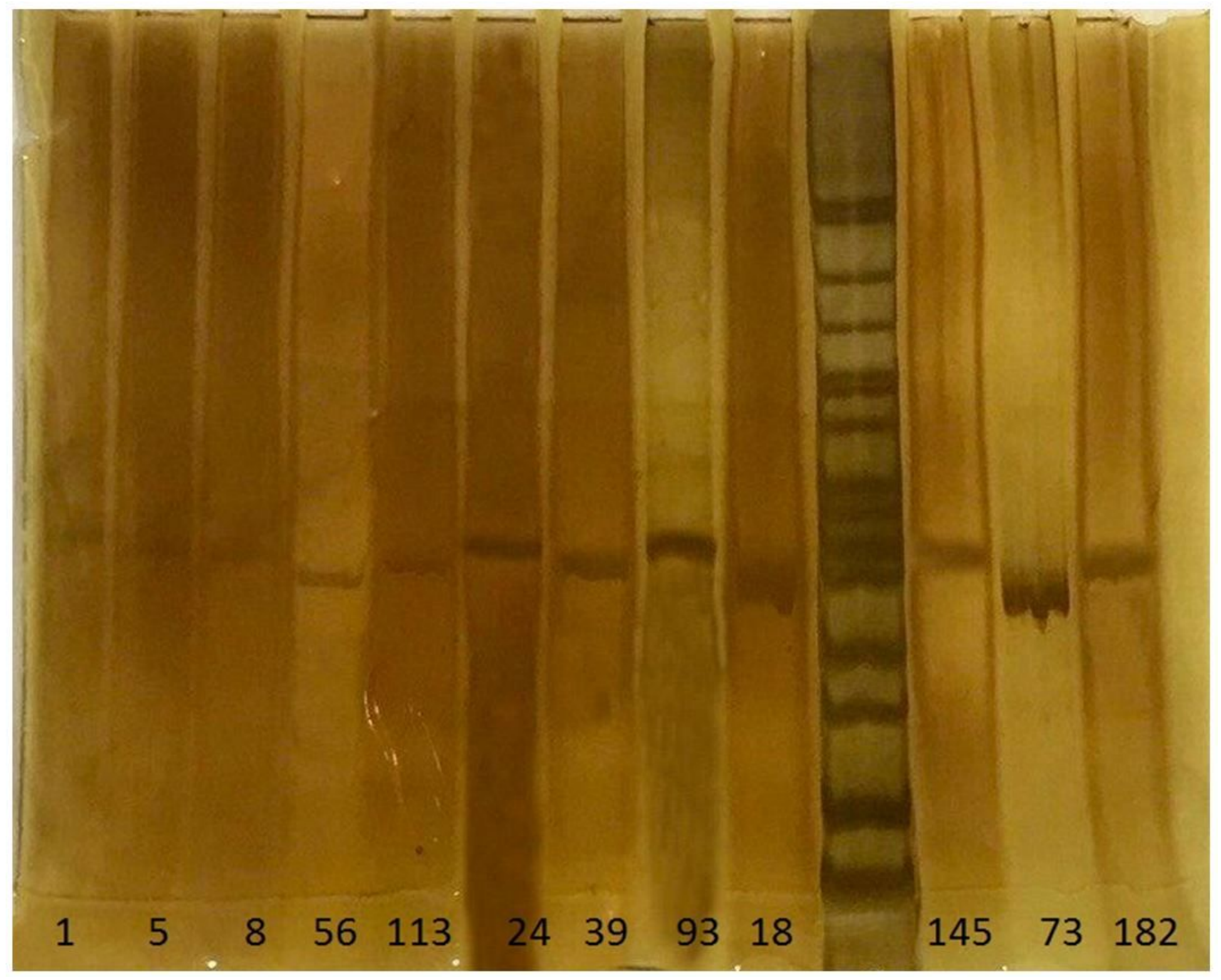

Figure 6

AR- CAG repeat expansion amplification in $8 \%$ acryl amid gel by $50 \mathrm{bp}$ ladder 


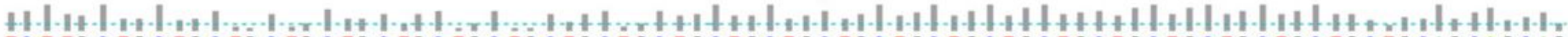

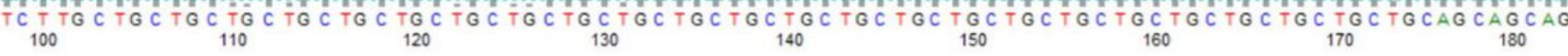

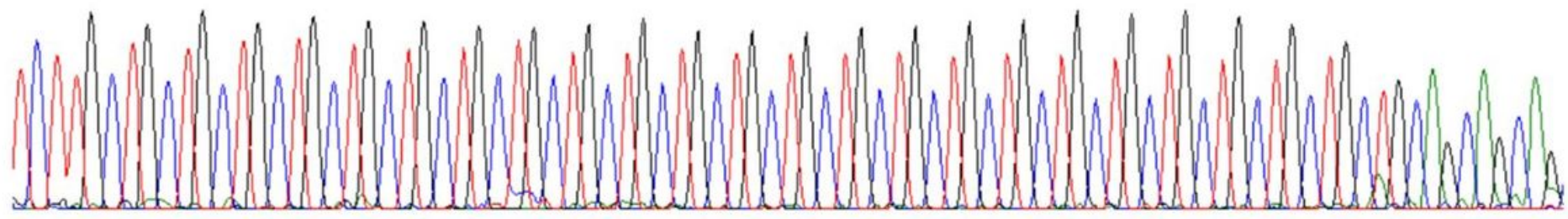
20 CAG repeat

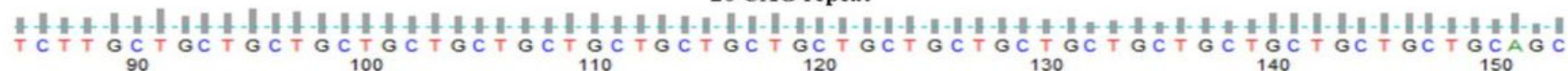

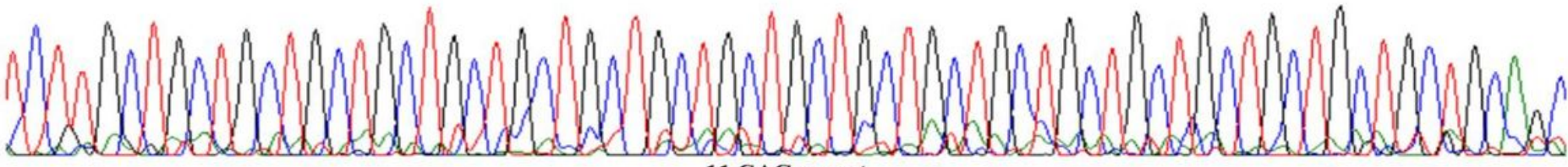
11 CAG repeat

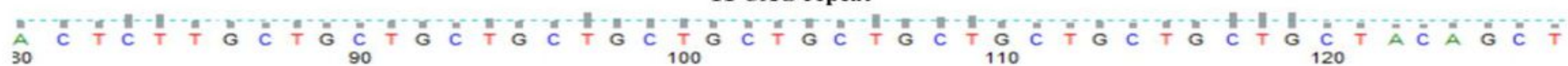

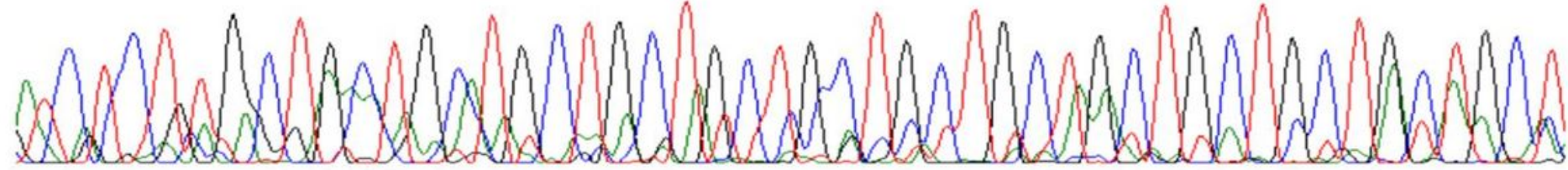

Figure 7

Sequencing graphs of the AR-CAG expansion

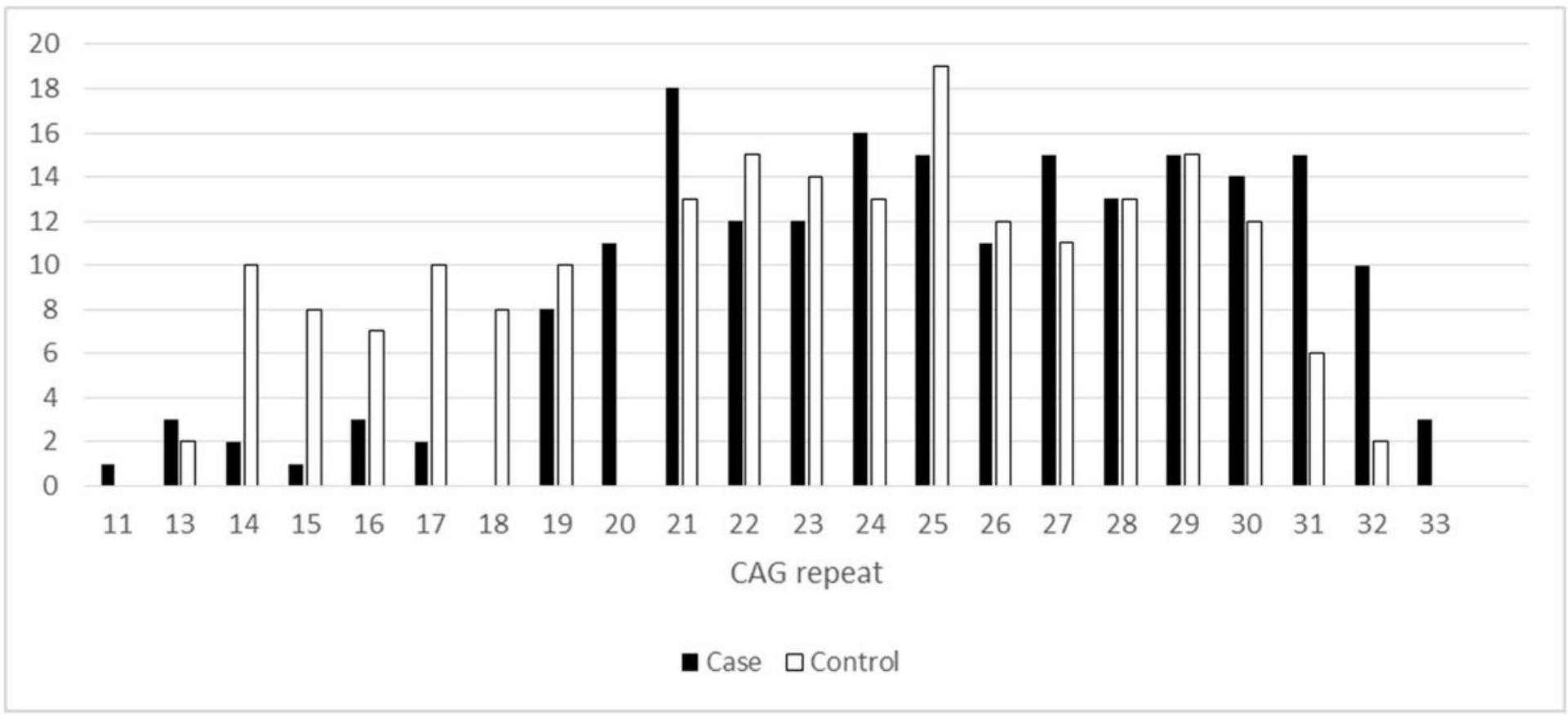

Figure 8 
Androgen receptor-CAG repeat distribution pattern in case and control groups 